\title{
Assessment of Soil Physical Analysis for Reclamation of Soil of Jiribam District, Imphal East, Manipur, India
}

\author{
Abujam Manglemkhombi Devi*, Narendra Swaroop \\ and Arun Alferd David Tarence Thomas
}

Department of Soil Science and Agriculture Chemistry, Sam Higginbottom University of Agriculture, Technology \& Science, Prayagraj-211007, U.P., India

*Corresponding author

\section{A B S T R A C T}

\section{Keywords}

Jiribam district, Physical properties, Soil color, Soil condition etc.

Article Info

Accepted:

22 July 2020

Available Online:

10 August 2020
An assessment of physical properties of soil of "Jiribam district" an area of Manipur, India was carried out in 2019-20. The prime objective of this study was collection of information from sampling sites and analysis of physical properties of soil, to make more aware to the farmers. For assessment 9 sampling sites were selected. Soil sample were collected with respect to depth $0-15 \mathrm{~cm}$ and $15-30 \mathrm{~cm}$. The study revealed that mean particle density ranges from 2.355 to $3.4 \mathrm{~g} / \mathrm{cc}$, mean bulk density from 1.05 to $1.14 \mathrm{~g} / \mathrm{cc}$, mean pore space range from $70.13 \%$ to $56.87 \%$ and mean solid space in between $43.42 \%$ to $29.83 \%$. The mean water holding capacity range from $80.15 \%$ to $66.15 \%$ and the mean specific gravity of soil is range from 2.265 to 1.57 . Soil texture classes were silty clay to silty loam soil. The soil color found in this region is varied from place to place. Light gray, light yellow brown, olive brown and grayish brown are the most prominent color of these selected sites. It clearly indicated that soil is rich in organic matter and ferrous oxide. A very good water holding capacity of soil and has good physical condition observed.

\section{Introduction}

Soil health is the capacity of soil to function as a vital living system, within ecosystem and land used boundaries, to sustain plant and animal productivity maintain or enhance water and air quality, and promote plant and animal health. Anthropogenic reduction in soil health, and of individual components of soil quality, are a pressing ecological concerned (Doran and Zeiss, 2000). The determination of soil quality and health is the combined result of soil fertility, biological degradation (decline of organic matter, 
biomass, decrease in activity and diversity of soil fauna), increase in erodibility, acidity, and salinity, and exposure of compact subsoil of poor physicochemical properties. Northeast India is characterized by high soil acidity, toxicity, heavy soil, and carbon loss, severe water scarcity during most part of year though it is known as high rainfall area. The problem soil is those, which owing to land or soil characteristic cannot be used for the cultivation of crop without adopting proper reclamation measures. Highly eroded soil, ravine land, soil on steeply sloping lands etc. constitute one set of problem soil. Acid soil, saline soil and alkaline soil constitute another set of problem soil (Saha et al., 2012). Soil degradation has raised some serious debate and it is an important issue in the modern era, it refers to decline in soil inherent capacity to produce economic goods and perform economic function. It is the net result of dynamic soil degradative and restorative soil process regulated by the natural and anthropogenic factors. The degree of soil degradation depends on soil susceptibility to degradative process, land use, the duration of degradative land use and the management. Among the anthropogenic shifting cultivation play a major role in hilly regions of North East India. 1/3th of the total cultivated land is degraded by shifting cultivation. Thus, create heavy soil erosion in this area. with all this fact in concern, the present work attempted to analyse the physical parameters of Jiribam soil of Manipur. The main reason to study this area is to evaluate soil health status at various depth by analysing the physical properties of soil. So that to make recommendation towards achieving sustainable utilization and agricultural production. The most important reason for choosing this area is that as of very less research paper in this region most of the farmers are not aware about theresoil condition. Thus, still they are dependent on conventional method without implementing advance technology.

\section{Materials and Methods}

\section{Site details}

Manipur is a state of North East India. Geographical area of 22,347 Sqkm and cultivable land $2117 \mathrm{Sqkm}$ and forest cover $1,699 \mathrm{Sqkm}$ which is $75.46 \%$ of state geographical area. District Jiribam lies in western part of Manipur at border of Assam. District lies in $2^{4^{\circ}} 48^{\prime} 0.00^{\prime \prime} \mathrm{N}$ Latitude and $9^{3^{0}} 07^{\prime} 12.00^{\prime \prime} \mathrm{E}$ Longitude. Soil sample were taken from Jiribam district of Manipur. Jiribam is highly humid throughout the year. The highest relative humidity occurs during monsoon season, more than $96 \%$. It is maximum of $100 \%$ and minimum of $79 \%$ in June. Certain type of soil found in Jiribam town and its environment that are mainly well drained except in few flat lands. It varies from sandy to loam and clay to loam and silty clay loam, having variety of color from yellowish to bluish gray (Fig. 1).

The plain has formation of fertile alluvial deposition by the Jiri river. The rainfall is abundant compared to other places of the state. most of the rainfall $90 \%$ is in the form of precipitation. about $20-30 \%$ of annual rainfall occur in rainy season, second half of June to September, ranging from $1000 \mathrm{~mm}$ to $1600 \mathrm{~mm}$. It constitutes till November in small quantity while that of pre-monsoon is in the form of thunder and shower. A meager quantity of frost is also found in between second half of December.

\section{Soil sampling}

Soil sample were collected from different areas within the Jiribam district region having variation in color, slope/ topography. Soil is collected from nine sites with a depth of 0 $15 \mathrm{~cm}$ and $15-30 \mathrm{~cm}$. The soil sample were transferred into air tight polythene bags and brought to the Laboratory for further analysis. 


\section{Sampling location}

Sample selected village of Jiribam district are Lakhipur, Kamranga and Hilghat. The exact location is assimilated with the help of global positioning system (GPS).

\section{Laboratory analysis}

The collected soil sample were examining for various physical parameters such as soil color, texture, pore space, solid space, bulk density (B.D), particle density (P.D), specific gravity, water holding capacity (WHC) of soil. The soil color has been compared with Universally accepted Munsell colorchart. All the parameters were analyses as per the method Manual Soil, Plant and Water Analysis, Dr.P.C. Jaiswal

\section{Result and Discussion}

\section{Soil texture}

The soil texture (Sand, Silt and clay\%) of different village of Jiribam district region, Manipur, India (Table 1). The soil texture was found in three different village are silty clay and silty clay loam. The minimum percentage of sand, silt and clay found in three different regions were $15.6 \%$ (Lakhipur), $37.95 \%$ (kamranga) and $34.71 \%$ (Hilghat) respectively. The maximum sand $\%$ is in Kamranga $(22.32 \%)$, silt is in Hilghat (43.52\%) and Clay \%is maximum in Lakhipur (41.08). Soil texture refers to the relative percentage of sand, silt and clay within a soil layer. Only particle $<2 \mathrm{~mm}$ in equivalent spherical diameter (e.s.d) are included in soil texture descriptions because most physicochemical activity is in this fine size fraction. Soil texture and textural are especially important aspect of modern soil research because they affect water holding capacity and base saturation, which related to agronomic productivity.

\section{Soil color}

The soil color (Dry method) of three different village of Jiribam district, Imphal East, Manipur. The soil color of the village varies from brown to gray color. The sample of Lakhipur and Hilghat is mostly of lightyellow brown in color. Whereas the Kamranga soil is light gray color. The soil color (wet method) of most of the village found is light brown gray, olive brown and grayish brown. Kamranga soil is dominant by grayish brown color and Hilgh at soil color is olive brown to light olive brown color. The soil color is often determined by the presence of iron oxide and organic matter. When the presence of iron oxide dominates than organic matter, it appears from brown to reddish brown color (Woperis et al., 2009). Most of the soil appear gray or greenish brown by the presence of reduce (ferrous) iron oxide. The presence of other material can also affect soil color, manganese oxide causes black color, glauconite make the soil green and calcite make the soil arid and appears white color (Table 2 and 3 ).

\section{Bulk density}

In village the maximum mean bulk density was found at Lakhipur $\left(\mathrm{S}_{1}\right)$ and minimum bulk density is found Kamranga $\left(\mathrm{S}_{5}\right)$ and Hilghat $\left(\mathrm{S}_{8}\right)$. The bulk density decreases with increases soil depth. Different level of erosion of soil depending upon the slop and management. Soil particles also responsible for higher bulk density which might be due to greater compaction that might have occurred in the lower horizon of the soil profile with time. Bulk density is dependent on soil organic matter, soil texture, the density of soil mineral (sand, silt, and clay) and their packing arrangement. As a rule of thumb, most rocks have a density of $2.65 \mathrm{~g} / \mathrm{cm}^{3}$ so ideally, a silt loam soil has $50 \%$ pore space and a bulk density of $1.33 \mathrm{~g} / \mathrm{cm}^{3}$ (Fig. 2 and Table 4). 
Table.1 Evaluation of soil texture of different soil of Jiribam district Manipur

\begin{tabular}{|l|c|c|c|c|}
\hline Village & Sand \% & Silt \% & Clay \% & Textural class \\
\hline LAKHIPUR & 15.6 & 42.6 & 41.08 & Silty clay \\
\hline KAMRANGA & 22.32 & 39.73 & 37.95 & Silty clay loam \\
\hline HILGHAT & 21.77 & 43.52 & 34.71 & Silty clay loam \\
\hline
\end{tabular}

Table.2 Soil color (Dry method) of different depth $(0-15 \mathrm{~cm}$ and $15-30 \mathrm{~cm})$ of three different village of Jiribam district, Manipur

\begin{tabular}{|c|c|c|c|}
\hline \multicolumn{2}{|l|}{ Village } & $0-15 \mathrm{~cm}$ Depth & $15-30 \mathrm{~cm}$ Depth \\
\hline \multirow[t]{3}{*}{ Lakhipur } & $\mathrm{S}_{1}$ & $2.5 \mathrm{Y}, 7 / 2$ light gray & $\begin{array}{l}2.5 \mathrm{Y}, 6 / 2 \text { light brownish } \\
\text { gray }\end{array}$ \\
\hline & $\mathrm{S}_{2}$ & $\begin{array}{l}2.5 \mathrm{Y}, 6 / 4 \quad \text { light } \quad \text { yellow } \\
\text { brown }\end{array}$ & 2.5Y,6/4 light yellow brown \\
\hline & $\mathrm{S}_{3}$ & $2.5 \mathrm{Y}, 7 / 2$ light gray & $2.5 Y, 6 / 4$ light yellow brown \\
\hline \multirow[t]{3}{*}{ Hilghat } & $\mathrm{S}_{4}$ & $\begin{array}{l}2.5 \mathrm{Y}, 6 / 4 \text { light yellow } \\
\text { brown }\end{array}$ & $2.5 \mathrm{Y}, 6 / 4$ light yellow brown \\
\hline & $\mathrm{S}_{5}$ & $\begin{array}{l}2.5 \mathrm{Y}, 6 / 4 \text { light } \quad \text { yellow } \\
\text { brown }\end{array}$ & $\begin{array}{llll}2.5 \mathrm{Y}, & 6 / 4 & \text { light } & \text { yellow } \\
\text { brown } & & & \\
\end{array}$ \\
\hline & $\mathrm{S}_{6}$ & $\begin{array}{l}2.5 \mathrm{Y}, 6 / 4 \quad \text { light } \quad \text { yellow } \\
\text { brown }\end{array}$ & 2.5Y,5/4 light olive brown \\
\hline \multirow[t]{3}{*}{ Kamranga } & $\mathrm{S}_{7}$ & $2.5 Y, 7 / 2$ light gray & $2.5 Y, 7 / 2$ light gray \\
\hline & $\mathrm{S}_{8}$ & $2.5 \mathrm{Y}, 7 / 2$ light gray & 2.5Y,7/2 light gray \\
\hline & $\mathrm{S}_{9}$ & $2.5 \mathrm{Y}, 7 / 2$ light gray & $2.5 Y, 7 / 2$ light gray \\
\hline
\end{tabular}

Table.3 Soil color (wet method) of three different village of Jiribam district, Manipur

\begin{tabular}{|l|l|l|l|}
\hline Village & & $\mathbf{0 - 1 5} \mathbf{c m}$ Depth & $\mathbf{1 5}-\mathbf{3 0}$ cm Depth \\
\hline \multirow{4}{*}{ Lakhipur } & $\mathrm{S}_{1}$ & $2.5 \mathrm{Y}, 6 / 2$ light brown gray & $2.5 \mathrm{Y} 4 / 4$ Olive Brown \\
\cline { 2 - 4 } & $\mathrm{S}_{2}$ & $2.5 \mathrm{Y}, 5 / 2$ Grayish brown & $2.5 \mathrm{Y}, 5 / 4$ Light olive brown \\
\cline { 2 - 4 } & $\mathrm{S}_{3}$ & $2.5 \mathrm{Y}, 5 / 2$ grayish brown & $2.5 \mathrm{Y}, 4 / 2$ Dark grayish brown \\
\hline \multirow{4}{*}{ Hilghat } & $\mathrm{S}_{4}$ & $2.5 \mathrm{Y}, 4 / 4$ olive brown & $2.5 \mathrm{Y} 4 / 4$ Olive brown \\
\cline { 2 - 4 } & $\mathrm{S}_{5}$ & $2.5 \mathrm{Y}, 4 / 4$ Olive brown & $2.5 \mathrm{Y}, 5 / 4$ light olive brown \\
\cline { 2 - 4 } & $\mathrm{S}_{6}$ & $2.5 \mathrm{Y}, 4 / 4$ Olive brown & $2.5 \mathrm{Y}, 5 / 4$ light olive brown \\
\hline \multirow{3}{*}{ Kamranga } & $\mathrm{S}_{7}$ & $2.5 \mathrm{Y}, 5 / 2$ Grayish brown & $2.5 \mathrm{Y}, 5 / 2$ Grayish brown \\
\cline { 2 - 4 } & $\mathrm{S}_{8}$ & $2.5 \mathrm{Y}, 5 / 2$ Grayish brown & $2,5 \mathrm{Y}, 5 / 2$ Grayish brown \\
\cline { 2 - 4 } & $\mathrm{S}_{9}$ & $2.5 \mathrm{Y}, 5 / 2$ Grayish brown & $2.5 \mathrm{Y}, 5 / 2$ Grayish brown \\
\hline
\end{tabular}


Table.4 Physical properties of soil with two depth $(0-15 \mathrm{~cm}$ and $15-30 \mathrm{~cm})$ of three different village

\begin{tabular}{|c|c|c|c|c|c|c|c|c|c|c|c|c|c|c|c|c|c|c|}
\hline \multirow[t]{4}{*}{ Parameters } & \multicolumn{18}{|c|}{ Village Name } \\
\hline & \multicolumn{6}{|c|}{ Lakhipur } & \multicolumn{6}{|c|}{ Kamranga } & \multicolumn{6}{|c|}{ Hilghat } \\
\hline & \multicolumn{3}{|c|}{$0-15 \mathrm{~cm}$} & \multicolumn{3}{|c|}{$15-30 \mathrm{~cm}$} & \multicolumn{3}{|c|}{$0-15 \mathrm{~cm}$} & \multicolumn{3}{|c|}{$15-30 \mathrm{~cm}$} & \multicolumn{3}{|c|}{$0-15 \mathrm{~cm}$} & \multicolumn{3}{|c|}{$15-30 \mathrm{~cm}$} \\
\hline & $\mathrm{S}_{1}$ & $\mathrm{~S}_{2}$ & $\mathrm{~S}_{3}$ & $\mathrm{~S}_{1}$ & $\mathrm{~S}_{2}$ & $\mathrm{~S}_{3}$ & $\mathrm{~S}_{4}$ & $\mathrm{~S}_{5}$ & $\mathrm{~S}_{6}$ & $\mathrm{~S}_{4}$ & $\mathrm{~S}_{5}$ & $\mathrm{~S}_{6}$ & $\mathrm{~S}_{7}$ & $\mathrm{~S}_{8}$ & $\mathrm{~S}_{9}$ & $\mathrm{~S}_{7}$ & $\mathrm{~S}_{8}$ & $\mathrm{~S}_{9}$ \\
\hline $\begin{array}{l}\text { Bulk } \\
\text { density }\end{array}$ & 1.11 & 1.05 & 1.05 & 1.17 & 1.11 & 1.17 & 1.11 & 1.05 & 1.05 & 1.11 & 1.05 & 1.11 & 1.05 & 1.05 & 1.05 & 1.11 & 1.05 & 1.17 \\
\hline $\begin{array}{l}\text { Particle } \\
\text { density }\end{array}$ & 3.0 & 2.71 & 3.16 & 2.42 & 2 & 2.12 & 3 & 2.71 & 3.16 & 2.25 & 2.37 & 2.25 & 3.8 & 3.8 & 3.1 & 3 & 2.71 & 2.83 \\
\hline Pore space & 66.66 & 63.15 & 68.42 & 58.82 & 50.00 & 52.94 & 66.66 & 63.15 & 68.42 & 55.55 & 57.89 & 55.55 & 73.60 & 73.60 & 68.42 & 66.66 & 63.15 & 64.70 \\
\hline Solid space & 33.33 & 36.84 & 31.57 & 41.17 & 50.00 & 47.05 & 33.33 & 36.84 & 31.57 & 44.44 & 42.10 & 44.44 & 26.31 & 26.31 & 31.57 & 33.33 & 36.84 & 35.29 \\
\hline $\begin{array}{l}\text { Specific } \\
\text { gravity }\end{array}$ & 2.02 & 1.73 & 1.72 & 2.26 & 2.16 & 2.14 & 2.13 & 1.40 & 1.83 & 2.40 & 1.74 & 2.09 & 1.76 & 1.70 & 1.86 & 1.81 & 1.83 & 1.85 \\
\hline $\begin{array}{l}\text { Water } \\
\text { holding } \\
\text { capacity }\end{array}$ & 81.08 & 81.08 & 71.05 & 80.00 & 80.55 & 69.44 & 76.31 & 74.35 & 69.23 & 70.27 & 73.68 & 67.56 & 69.23 & 76.92 & 68.42 & 63.15 & 64.86 & 63.88 \\
\hline
\end{tabular}


Fig.1 Satellite map of sampling sites of Jiribam district

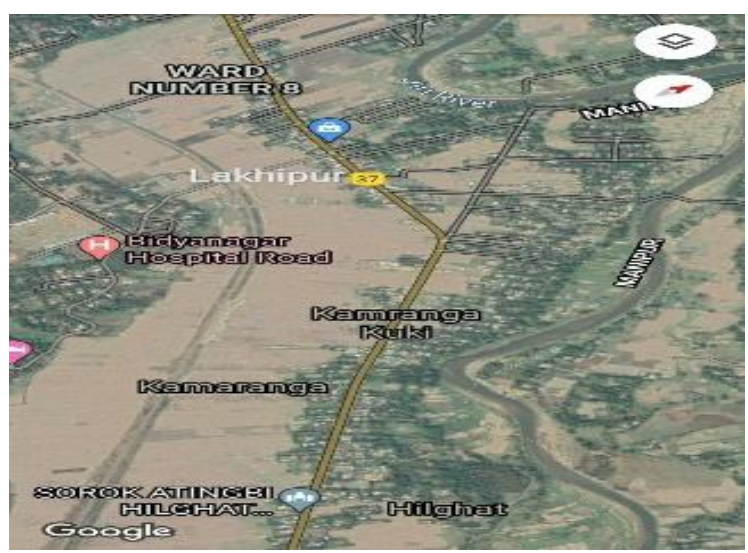

Fig.2 Bulk density of soil with two depth (0-15 cm and $15-30 \mathrm{~cm})$

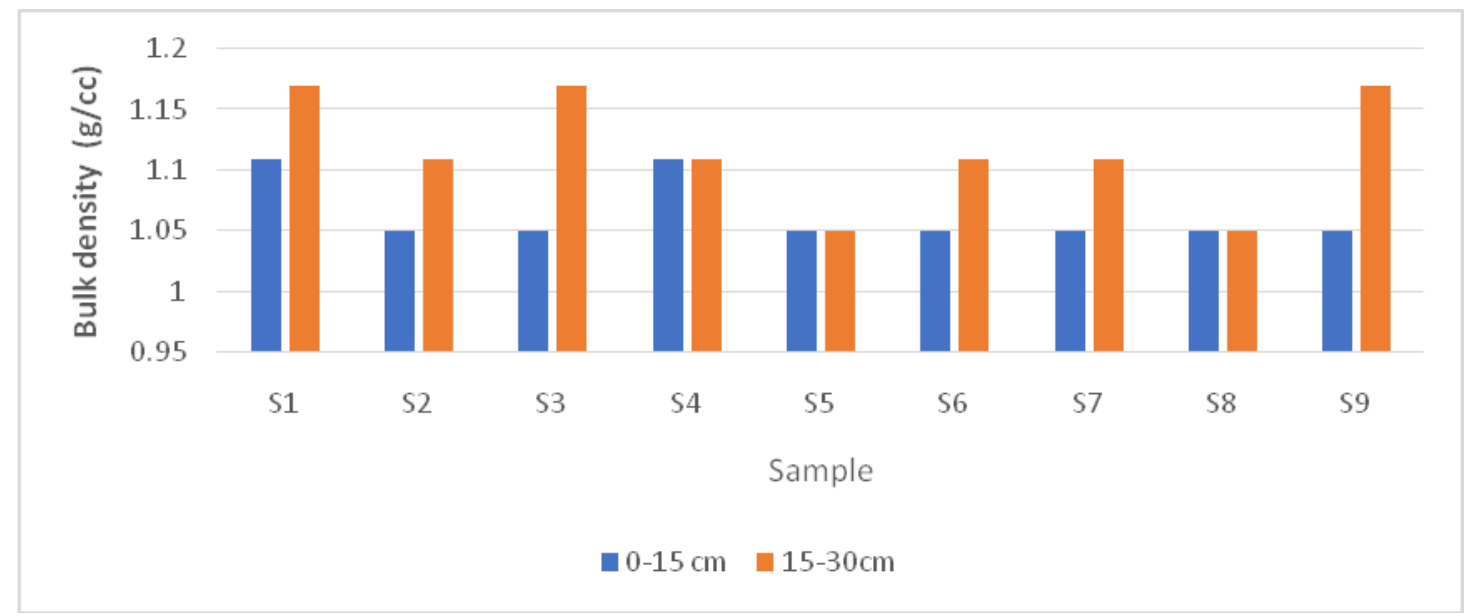

Fig.3 Particle density of soil with two depth $(0-15 \mathrm{~cm}$ and $15-30 \mathrm{~cm})$

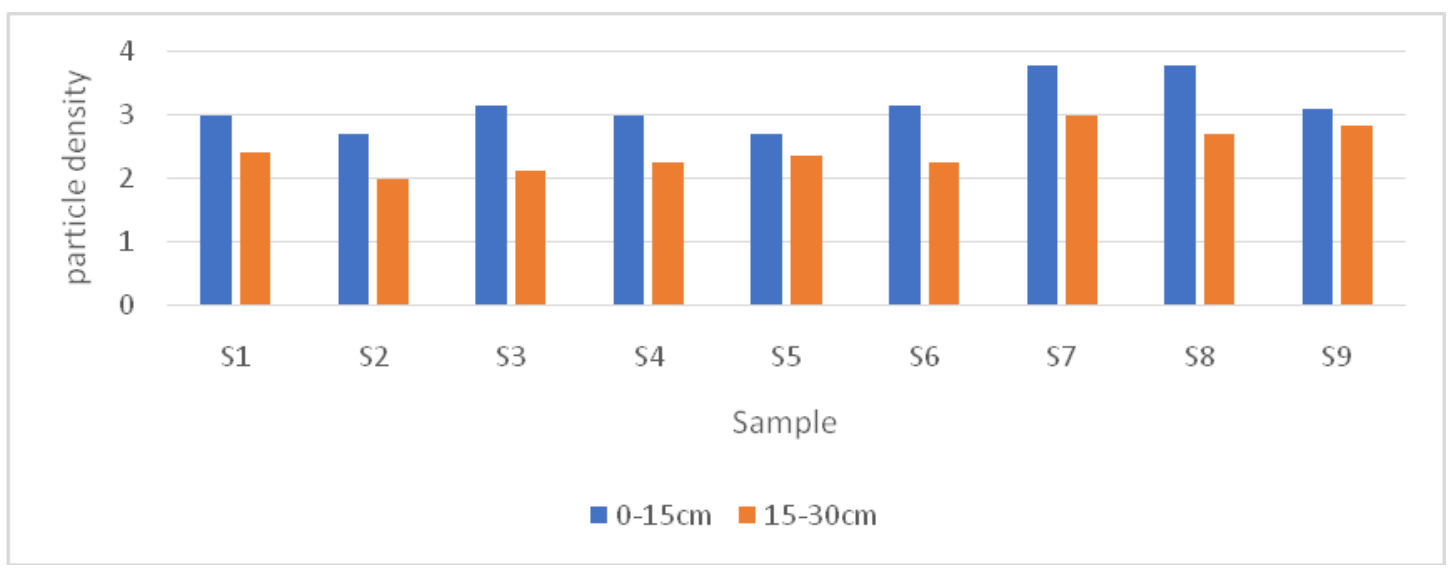


Fig.4 Pore space of soil with two depth $(0-15 \mathrm{~cm}$ and $15-30 \mathrm{~cm})$

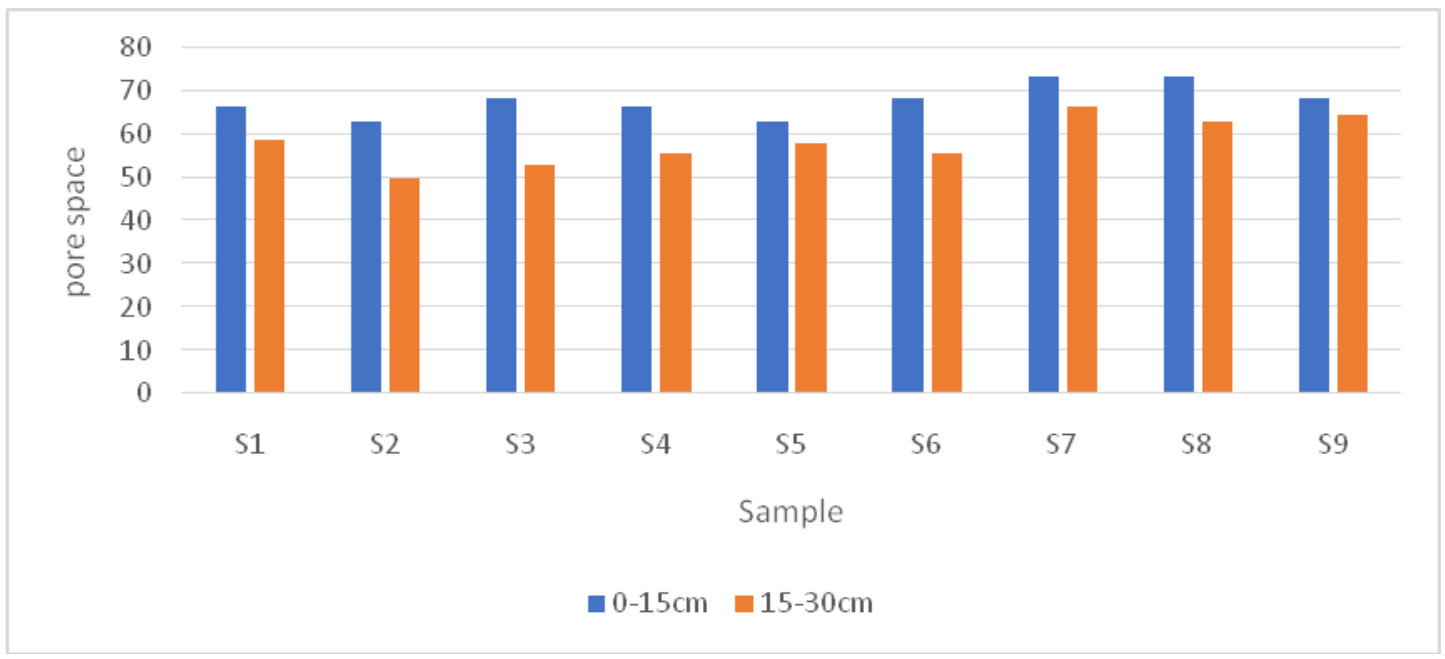

Fig.5 Solid space of soil with two depth $(0-15 \mathrm{~cm}$ and $15-30 \mathrm{~cm})$

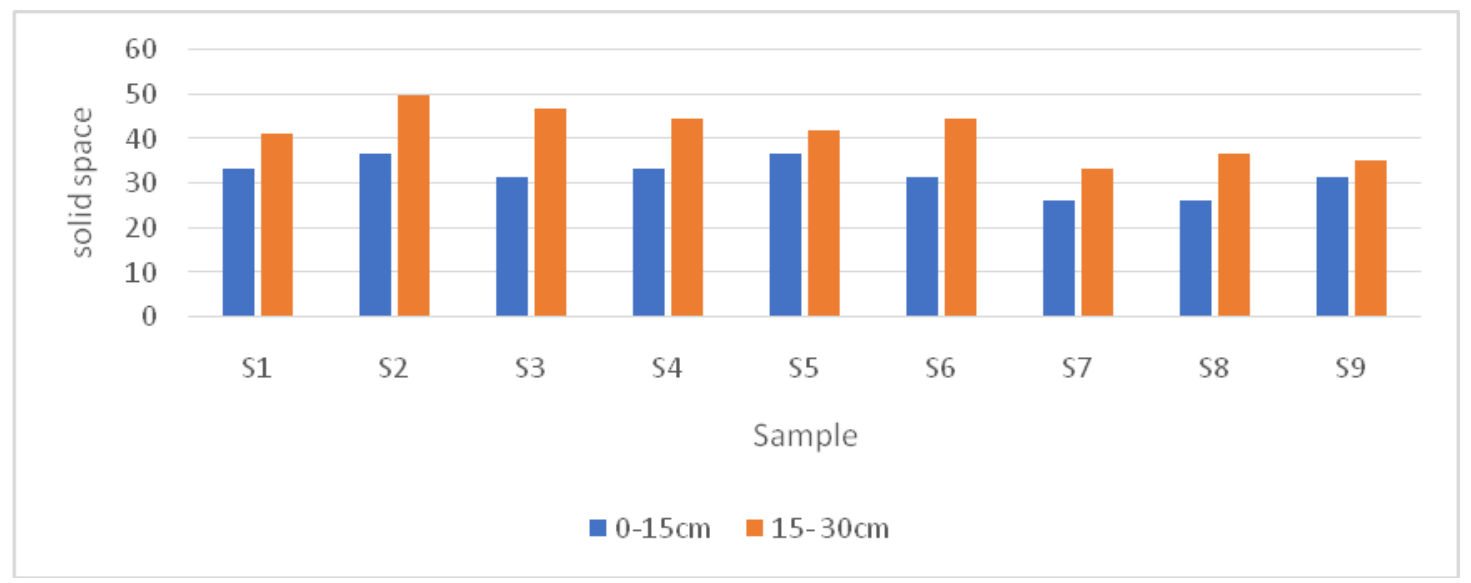

Fig.6 Specific gravity of soil with two depth $(0-15 \mathrm{~cm}$ and $15-30 \mathrm{~cm})$

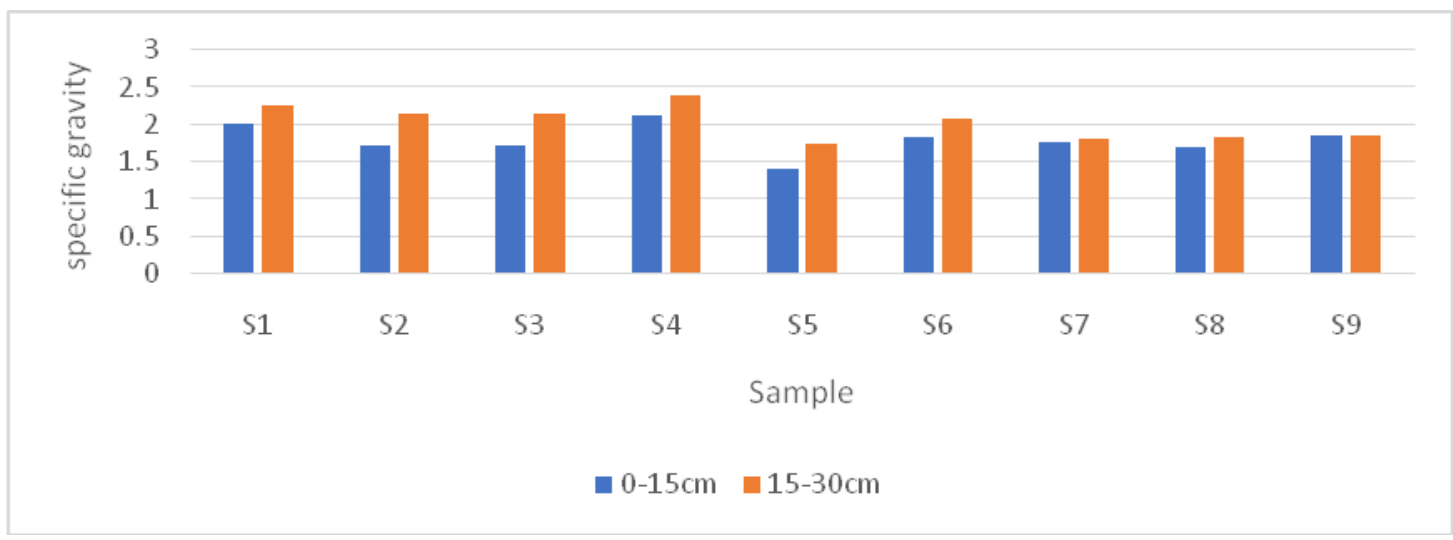


Fig.7 Water Holding Capacity of soil with two depth $(0-15 \mathrm{~cm}$ and $15-30 \mathrm{~cm})$

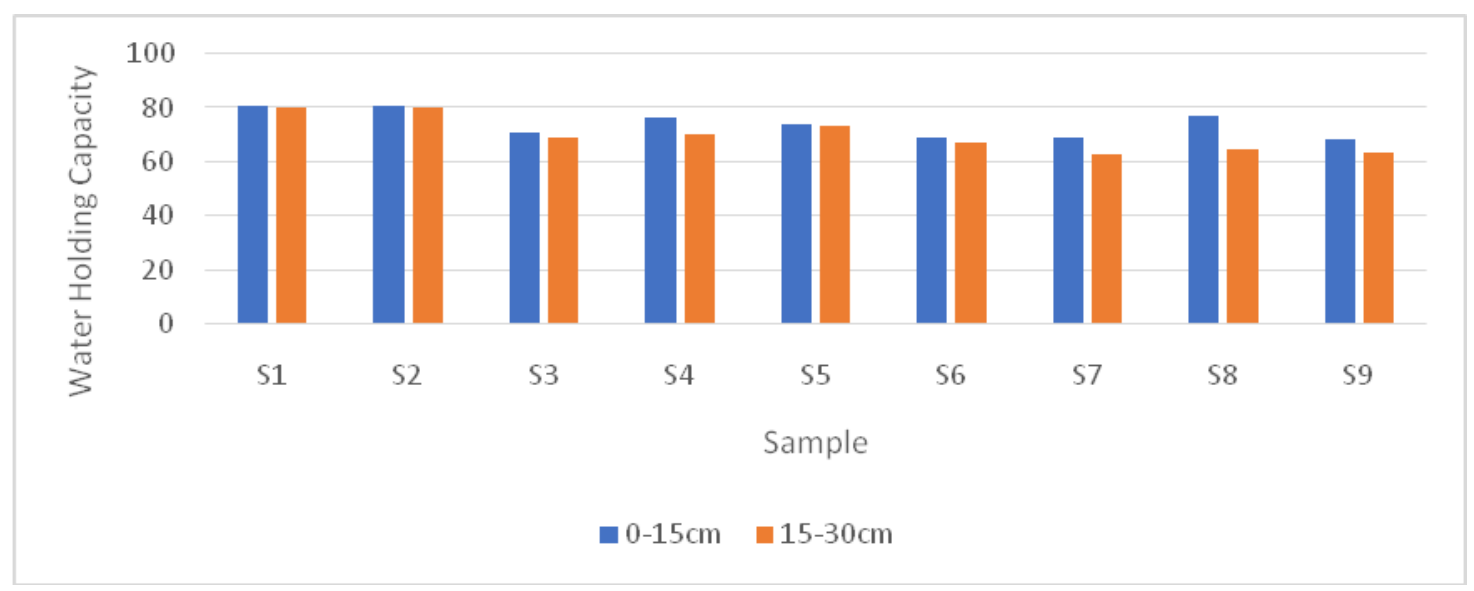

\section{Particle density}

Particle density is the density of the solid particles that collectively make up a soil sample. The value is commonly expressed in grams per cubic centimeter. The common range among soils is 2.55 to $2.70 \mathrm{~g}$ $\mathrm{cm}^{-3}$ the highest mean particle density is found at Hilghat $\left(\mathrm{S}_{7}\right)$ and lowest is at Lakhipur $\left(S_{2}\right)$. Particle density varied according to mineral contain of the soil particle. It doesn't usually very a lot in moist soil (Fig. 3).

\section{Pore space}

The highest mean pore space $\%$ was found at Hilghat $\left(\mathrm{S}_{7}\right)$ of $70.13 \%$ and lowest mean Pore space is at Lakhipur village $\left(\mathrm{S}_{2}\right)$ of $56.87 \%$. The pore space of soil contains the liquid and gas phases of soil. In order to understand porosity better a series of equation have been used to express the quantitative interactions between the three phases of soil (Fig. 4).

\section{Solid space}

In village the highest solid space is at Lakhipur $\left(\mathrm{S}_{2}\right)$ and the lowest is at Hilghat $\left(\mathrm{S}_{7}\right)$. The solid phase that contains mainly minerals of varying sizes as well as organic compound (Fig. 5).

\section{Specific gravity}

In village the maximum mean specific gravity was found at Kamranga $\left(\mathrm{S}_{4}\right)$ and lowest at Kamranga $\left(\mathrm{S}_{5}\right)$. The specific gravity of the soil particles lies within the range of 2.65 to 2.85. Soils containing organic matter and porous particles may have specific gravity values below 2.0. Soils having heavy substances may have values above 3.0 (Fig. $6)$.

\section{Water holding capacity (\%)}

Water Holding Capacity is the ability of a certain soil texture to physically hold water against the force of gravity. It does this by soil particles holding water molecules by the force of cohesion. As an example, a sandier soil has much less water holding capacity than a silt loam soil.

In village the highest mean water holding capacity was found at Lakhipur $\left(\mathrm{S}_{2}\right) 80.815 \%$ and lowest is at Hilghat $\left(\mathrm{S}_{9}\right) 66.15 \%$. The variation was due to the silt, clay and organic carbon content and low water holding capacity in sandy soil due to high sand and less silt content. The irregular trend of water holding capacity with depth was due to the illuviation and eluviation ion of finer fraction in different horizon (Fig. 7). 
As the result above concluded the physical condition of soil is good. Soil has very good water holding capacity and the electrical conductivity value found is good and won't affect the germination of seed.

\section{Acknowledgement}

It gives me immense pleasure, a sense of thanks and gratitude for encouragement during my study and investigation, head of department and staff of Soil Science and Agricultural Chemistry. Sam Higginbottom University of agriculture, technology and science, Prayagraj, Uttar Pradesh.

\section{References}

Athokpam, H, Wani S.H, Kamei, D. Singh, A.H. Nongthombam, J Kumar, D. Singh, Y.K. Singh, B.N. Devi, T.R and Devi, (2013) soil macro and micro Nutrient status of Senapati district of Manipur (India). African Journal of Agricultural research 8(39): 4932-4936.

Amachar et al., (2007) studied that the chemical and physical properties of soils to address specific question about forest soil quality and health.

Anonymous (1971) Munsell soil color chart, Munsell color company inc.2241N, Calvert street Baltimore Marytanel 21212, USA.

Chemlila Sangtam, Y.K. Sharma and S.K. Sharma (2017): Fertility Status and Forms of Acidity in Soils of Tuensang District, Nagaland in Relation to Land Use System, Journal of Indian Society of Soil Science.65(4)387-392.

Das, D.K., (2015) Introductory soil science, Fourth Revised \& Enlarged Edition, Kalyani Publishers. New Delhi.

Jain, P and Singh, D. (2014) Analysis the Physico - Chemical and Microbial diversity of different variety of soil collected from Madhya Pradesh, India. Journal of Agriculture Science 4(20);
103-108.

Jacob S. Joffe (1949) Pedology, second edition, Pedology publication Newbrunswick. New Jersey, 662(30).

Marami Datta, R.M. Karmakar, K. Borkakati and BipulDeka (2017): Characterization and Classification of Soil of Tipukjan watershed of the Upper Brahmaputra Valley of Assam. Journal of the Indian Society of Soil Science, 65(4)349-359

Murthy, R.S., Shankaranarayana, H.S. and Hirekerur, L. R (1972) Approach to soil survey and soil classification J. Indian Society of Soil Science., 25; 284-287.

Namita Dutta, Samiron Dutt and R.M. Karmakar (2017): Characterization and classification of some alluvium derived soil under different land use in Jorhat district of Assam. Journal of Indian Society of Soil Science, 65(4); 360-368.

NBSS and LUP staff (1984) Benchmark soil series of India: Mondha seriesCharacteristics, classification and Interpretation for Land Use Planning Bulletin No. 15, NBSS and LUP Publication, Nagpur, Pp. 24.

Pal, D.K., Bhattacharya, T., Chandran, p., Ray, S.K., Satyavathi, P.L.A., Raja, P., Maurya, U.K and Paranjape, M.V. (2006) Pedogenetic processes in a shrink -swell soil of central India. Agropedology, 16(1); 12-20.

Rajiv Rakshit, Anupam Das, Rajeev Padbhushan, Rajendra Prashad Sharma Sushant and Sanjay Kumar (2018): Assessment of Soil Quality and Identification of Parameters Influencing System Yield under long term fertilizer Trial. Journal of Indian Society of Soil Science, 66(2); 166-171

Siladitya Bandyopadhyay, P. Ray, S. Padua, S. Ramachandran, R.K. Jena, P. Deb Roy, D.P. Dutta, U. Baruah, K.D. Sah, S.K. Singh, D.C. Nayak and S.K.Ray (2018): Form of acidity in Soil Development on Different Landforms 
along an Altitudinal Sequence in Nagaland, India. Journal of the Indian Society of Soil Science, 66, (2);125-135.

Sahu, V.K. and David, A. A (2014) Soil health assessment of research farm of Allahabad school of Agriculture SHIATS DU Allahabad, The Allahabad Farmer Vol. LXI. No. 2.

Sarkar, D., Baruah, U., Gangopadhay, S.K., Sahoo, A.K. and Velayutham, M. (2002) Characteristic and classification of soil of Loktak common area of Manipur for sustainable land use planning. J. Indian Society of Soil Sci 50; 196-204.

Soil Survey Staff. (1999) Soil Taxonomy -A basic system of soil classification for making and interpreting soil surveys.
Second Edition, Agricultural Handbook No. 436, United State Department of Agriculture, Washington Dc, USA, pp.460.

Soil Survey Staff (1951) Soil Survey Manual, United state Department of Agriculture Handbook No.18, Washington, USA, p. 851-857.

Soil survey staff (1998) Key to soil Taxonomy English Edition. National Resource Conservation Center, USDA, Washington DC. p. 489-492.

Viji， R and Prasanna. P. Rajesh (2012) Assessment of water holding capacity of major soil series of Lalgudi, Trichy, India, Journal of Environmental Research and Development.

\section{How to cite this article:}

Abujam Manglemkhombi Devi, Narendra Swaroop and Arun Alferd David Tarence Thomas. 2020. Assessment of Soil Physical Analysis for Reclamation of Soil of Jiribam District, Imphal East, Manipur, India. Int.J.Curr.Microbiol.App.Sci. 9(08): 2799-2808. doi: https://doi.org/10.20546/ijcmas.2020.908.315 